\title{
Principles of Ensuring Appropriate Driving Conditions on Motor Roads
}

\author{
Kazys Petkevičius ${ }^{\mathrm{a}}$, Birute Petkevičienè ${ }^{\mathrm{b}}$ \\ ${ }^{a}$ Department of Roads, Vilnius Gediminas Technical University, Sauletekio al. 11, LT-10223 Vilnius, Lithuania \\ ${ }^{b}$ Department of Natural Science, Mathematics and Technology Didactics, Lithuanian University of Educational Sciences, \\ Studentų Str. 39, LT-08106 Vilnius, Lithuania
}

\begin{abstract}
Under conditions of increasing traffic volume and the growing percentage of heavy vehicles, it is necessary to ensure safe, fast and comfortable transportation of passengers as well as safe and fast transportation of cargo. Striving for assurance of such conditions, properties of motor roads, their road pavement and road pavement constructions (RPC) have to be sufficiently good: RP roughness, RPC strength, its state, etc. The roads and roadside zones have to be esthetical, interesting and attractive for travelling and to have a sufficient number of traffic service facilities: rest areas with hotels, restaurants, gas stations and other service objects, road signs and information posters, safety fences for pets and others. This article focuses on evaluation of motor roads considering driving conditions, esthetical, landscape formation, ecological aspects and need of establishment of service objects and their distribution. Following the results of the research conducted by the authors and other researchers, suggestions regarding rational distribution of service and rest objects in the roadside zones on the basis of evaluation of local conditions are provided. The dependence of RP roughness and RPC strength depend on the level of RPC disintegration. The authors point out how to reduce the level of RPC disintegration to ensure appropriate level of comfortable driving and safety of traffic.
\end{abstract}

Keywords: motor roads; motor vehicle (MV); driving conditions; functional use; road pavement (RP); road pavement construction (RPC); RP roughness; RPC strength; RPC disintegration level; service and rest objects; rational distribution; AC; SL.

\section{Introduction}

Since Lithuania joined the European Union (EU), the development of separate territorial units (regions) has become a topical issue. Natural and human resources, transport system have been efficiently employed in these regions and attempts have been made to rationally distribute industrial companies as well as other objects. Having evaluated experience accumulated in well-known euro-regions (Brussels, Mediterranean, etc.), it is possible to foresee the rational trends in improvement of Lithuanian transport system and motor roads as its most important component. Motor roads that link separate regions are particularly relevant in regional formation and development.

The research revealed [1] that in the climate zone of Lithuania and other neighbouring countries, where functioning conditions of road subgrade and pavement construction are very complicated and severe, as much as $35 \%$ of early disintegration of pavement is caused by insufficient strength of road pavement construction (RPC).

A rapidly growing number of vehicles in Lithuania (1.29 million in 2000 and 2.32 million in 2012) and an increasing proportion of heavy-weight multi-axial cargo vehicles in the flows of motor vehicles (MV) require establishment of conditions for safe, convenient and fast transportation of passengers and cargos. Pursuing assurance of the aforesaid conditions, appropriate roughness of asphalt concrete pavement, low-level disintegration of pavement and its construction, sufficient strength of pavement construction and cohesion between MV tires and pavement should be achieved. Driving is pleasant, when roads and roadsides are esthetical, interesting and attractive and safety zones or more distant areas offer a big number of service and safety objects: hotels, restaurants, cafeterias, gas stations, shops, rest area and others. Improving conditions for provision of services for passengers and MV drivers, roads and roadsides zones were evaluated considering architectural, esthetical, landscape formation, environmental protection aspects and need for establishment and distribution of service and rest objects. To rationally allocate finances, it is necessary to calculate rational distances among service and rest objects and distances between them and roads, to establish reasoned quality parameters of asphalt concrete pavement and its construction as well as rational durability of asphalt concrete pavement and its construction.

Corresponding author: Kazys Petkevičius. E-mail address: Kazys.Petkevicius@vgtu.lt

http://dx.doi.org/10.3846/enviro.2014.163

(C) 2014 The Authors. Published by VGTU Press. This is an open-access article distributed under the terms of the Creative Commons Attribution License, which permits unrestricted use, distribution, and reproduction in any medium, provided the original author and source are credited. 
The goal of this article is to determine appropriate conditions for driving motor roads.

The object of the research is the motor roads conditions for driving in Lithuania. Having evaluated the experience accumulated in operation and improvement of motor roads in Lithuania over the last years, the authors carried out research on proper conditions for driving on roads. The conducted research considered the following important aspects:

- considerable recent changes in state of motor roads and changing conditions of driving on them;

- contemporary requirements for motor roads, their pavement and pavement construction for safe conditions for driving on motor roads.

\section{Influence of various factors on the state of RP and RFC, their characteristics and service life}

Over the last years, due to growing impact of heavyweight load vehicles, the intensity of disintegration of RP and RPC has increased and the life service of them has been getting shorter in Lithuania.

The results of the research conducted in various countries have revealed an increasing rutting of AC pavement. This is an urgent problem of RP quality, which proves that grading resistant AC should be used in roads designed for intensive heavyweight traffic.

$\mathrm{AC}$ exposes to disintegration under influence of the following factors (in the course of time) [2-23]:

Destructive impact of motor vehicle and heavyweight cargo vehicles, in particular, causing fatigue cracks in AC pavement, which later form nets of cracks.

Impact of meteorological conditions:

a) sudden cooling of weather in winter, when velocity of cooling in AC pavement $v_{t}$, reaches $v_{t} \geq 6-10{ }^{\circ} \mathrm{C} / \mathrm{h} /$, transverse cracks appear in the pavement;

b) frequent changes in temperature, when temperature passages from negative to positive and vice versa (temperature of AC pavement $t$ changes and passages the temperature value $t=0{ }^{\circ} \mathrm{C}$ : in Lithuania such changes from positive to negative temperatures are observed about 60-80 times per year (one autumn-winter -spring season) or even more. Under such conditions, the pavement starts cracking and later even crumbling away, especially, in cases, when the AC of the pavement is not sufficiently compacted or when $\mathrm{AC}$ is not sufficiently erosion resistant;

c) solar radiation heats the AC pavement (on a clear day, when air temperature (reaches $t>30{ }^{\circ} \mathrm{C}$, the pavement is exposed to $60-70{ }^{\circ} \mathrm{C}$ ), which results in the following:

- more rapid ageing of the pavement, as evaporation of volatile oil fractions from bitumen in the AC pavement becomes more intensive and in 3 or 5 years it may start crumbling;

- considerable reduction of elasticity module of AC pavement results in softening of ACP, the strength of the whole RPC reduces; the patches of melted bitumen appear in the pavement because the volume of warm bitumen increases and it fills in hollows in AC pavement permeating through the surface of the pavement;

- reduction of AC resistance to shear stress produced by vehicles (heavy-weight vehicles in particular) results in ruts, waves, displacements and potholes. Insufficient adhesion of the upper and lower layer may result in movement of the upper one in respect to the lower one. As a result transverse cracks may appear.

Due to insufficient strength of RPC - transverse cracks are formed in AC pavement, which later may transform into spots and /or potholes. Finally (due to the aforesaid reasons) disintegration of $A C$ in the pavement will cause further deterioration of strength of $\mathrm{AC}$ of the pavement and the whole RC.

Due to insufficient RPC: (in the course of time) the whole RPC or its part under RP become very sensitive:

a) due to destructive impact of vehicles (heavy-load ones in particular),

b) due to climate factors:

- due to impact of negative temperature, when RPC contains poorly cohered layers that consist of low filtration capacity materials (with filtration coefficient lower than $3 \mathrm{~m} /$ day) - water may rise by capillaries of lauers higher to AC pavement (above the frozen ground) and freeze to ice lenses, whereof volume is higher than that of the water before freezing, which may result in bulges in different places and cracks in the surface of the pavement;

- due to impact of atmospheric waters: excessive rainfalls wet out the road bed, which reduces the elasticity module (clay in particular);

- due to impact of groundwaters: shallow groundwaters as well as melting snow irrigate the soil of subgrade and reduces the elasticity module of subgrade soil (clay in particular).

The results of the research carried out by AASHTO (USA) showed that $15 \%$ of the best functioning RP sectors may function 6-10 times as long compared to 15\% worst functioning sectors of the same road built according to the same design. Taking into consideration a 10 year period as average service life of RP, the sectors of shortest durability of service life would last 3-4 years, whereas the longest functioning sectors would serve 25-30 years. This shows that even the same RPC, the same standards, technologies, MV traffic and environmental conditions, do not guarantee identical level of RP deterioration. It is a natural process, which depends on various factors. The majority of them are accidental and, therefore, they cannot be measured and evaluated [24]. 


\section{The state of AC pavement and properties, state and service life of its construction as well as driving conditions}

The results of the research conducted by the authors [25] and other researchers showed that the level of AC disintegration $D$ is closely related to the international roughness index IRI $Y_{I R I}(\mathrm{~m} / \mathrm{km})$ and RPC strength $K_{s t}$, whereas the values of the index $D(\%)$ depend on the duration of service life $T$ (in years). The dependencies of received correlation regression revealed a close link of the analysed indices (values of coefficient $R^{2}$ changed from $R^{2}=0.884$ to $R^{2}=0.996$ ).

$$
\begin{gathered}
K_{s t}=2.41 D^{-0.321}, \quad\left(R^{2}=0.884\right) \\
Y=174 K_{s t}^{2}-526 K_{s t}+794 \quad\left(R^{2}=0.980\right) \\
D=0.313 T^{2}-0.406 T, \quad\left(R^{2}=0.996\right) \\
Y_{I R I}=9.12 D+1.29, \quad\left(R^{2}=0.828\right)
\end{gathered}
$$

The results of the research have revealed that the disintegration level $D$ is a decisive index of the state and quality of RP. Their permissible values $D_{1}=5-8 \%, D_{2}=8-16 \%$ and $D_{3}>16 \%$ have been determined, which may be used as criteria establishing the rational time span after which expeditious and preventive repairs of the pavement and major repairs of its construction are necessary.

The recent research on highways in Lithuania has shown that under conditions of increasing traffic volume and the percentage of heavy-weight vehicles in it, the tendency of dependencies of RP roughness $Y_{\text {IRI }}$ and its states (according to level of disintegration $D(\%)$ ) as well as rutting index (rut depth $H, \mathrm{~mm}$ ) are similar:

$$
\begin{aligned}
& Y_{I R I}=0.2765 D+1.09, \quad\left(R^{2}=0.877\right) \\
& Y_{I R I}=0.1464 H+0.29, \quad\left(R^{2}=0.913\right)
\end{aligned}
$$

The generalized results of the conducted research allow concluding that:

- Creating very good (convenient) VM driving conditions on highways (when $Y_{I R I} \leq 1.0 \mathrm{~m} / \mathrm{km}$ ), it is necessary to ensure that the rut depth in the AC pavement $H$ equals $H \leq 5 \mathrm{~mm}$, whereas the level of disintegration is $D=0 \%$;

- Ensuring appropriate (good) driving condition (when $Y_{I R I} \leq 2.0 \mathrm{~m} / \mathrm{km}$ ), the depth of rut $H$ should equal $H \leq 12 \mathrm{~mm}$, whereas disintegration level $D$ should total $D \leq 4 \%$.

\section{Conclusions}

1. The following factors make the most considerable impact on the functional conditions and service life (SL) of ACP and RCP: traffic loads (heavy-weight vehicles in particular; local climate and weather conditions, local soils (their properties) as well as other local factors(ground water level and soil moisture regime, pavement construction conditions; embankment or excavation, etc.).

2. The research revealed that the condition of AC pavement and RPC is very well reflected by the level of their disintegration $(D)$, whereas that of RPC is expressed by its strength $K_{s t}$. The article provides recommendations about the critical values of disintegration level, which necessitate repairs of AC pavement and major repairs of RPC.

3. The research on Lithuanian highways of the resent years has shown that under conditions of increasing traffic volume and growing percentage of heavy vehicles, the correlation between the index of their roughness $Y_{I R I}$ and indices of their pavement state $D$ and $H$ has remained close compared to correlation of analogous indicators of highway pavements established 25-30 years ago. Having generalized the research results, the critical values of indices $Y_{I R I}, D$ and $H$ have been provided to ensure convenient driving conditions in highways, as well as critical values of indices to guarantee appropriate (good) driving conditions on highways.

\section{References}

[1] Petkevičius, K.; Sivilevičius, H. 2000. Automobilių kelių asfaltbetonio dangos ir jos konstrukcijos reikiamos savybės ir racionali funkcionavimo trukme [Required Properties of road asphalt concrete pavement and its rational service life], Transportas [Transport Engineering] 15(4): 184-195.

[2] Petkevičius, K.; Žilionienè, D.; Vorobjovas, V. 2010. Functional conditions and state of hot mix asphalt pavement and its structure of Lithuanian motor roads, The Baltic Journal of Road and Bridge Engineering 5(1): 43-49. http://dx.doi.org/10.3846/bjrbe.2010.06

[3] Bhasin, A.; Castelo Branco, V. T. F.; Masad, E.; Little, D. N. 2009. Quantative comparison of energy methods to characterize fatique in asphalt materials, Journal of Materials in Civil Engineering 21(2): 83-92.

[4] Bakhrakh, G. S. 2008. Proiektirovaniie nezhostkikh dorozhnykh odezhd po kriteriiu ustalostnogo rastreskivaniia, Nauka i tekhnika v dorozhnoi otrasli 45(2): $32-34$

[5] Iaromko, V. N. 2008. O sovershenstvovanii proiektirovaniia dorozhnykh odezhd nezhestkogo tipa, Nauka i tekhnika v dorozhnoi otrasli 45(2): 28-31.

[6] Loria, L.; Sebaaly, P. E.; Hajj, E. Y. 2008. Long-term performance of reflective cracking mitigation technique in Nevada, Transportation Research Record 2044: 86-95. http://dx.doi.org/10.3141/2044-10 
[7] Hu, S.; Hu, X.; Zhou, F.; Walubita, L. F. 2008. SA-crack pro: New finite element analysis tool for pavement crack propagation, Transportation Research Record 2068: 10-19. http://dx. doi.org/10.3141/2068-02

[8] Li, J.; Mahoney, J. P.; Muench, S. T.; Pierce, L. M. 2008. Bituminous surface treatment protocol for the Washington state department of transportation, Transportation Research Record 2084: 65-72. http://dx.doi.org/10.3141/2084-08

[9] Ker, H.-W.; Lee, Y.-H.; Lin, Ch.-H. 2008. Prediction models for transverse cracking of jointed concrete pavements: Development with long-term pavement performance database, Transportation Research Record 2068: 20-31. http://dx.doi.org/10.3141/2068-03

[10] Dawson, A. 2008. Rut accumulation and power law models for-volume pavement under mixed traffic, Transportation Research Record 2068: 78-86.

[11] Tighe, S.; Huen, K.; Haas, R. 2007. Environmental and traffic deterioration with mechanistic-empirical pavement design model: Canadian example, Transportation Research Record 1989(2): 336-343.

[12] Seo, Y.; El-Haggan, O.; King, M.; Lee, S. J.; Kim, Y. R. 2007. Air Void models for the dynamic modulus, fatique cracking, and rutting of asphalt concrete, Journal of Materials in Civil Engineering 19(10): 874-883.

[13] Lee, H. J.; Park, H. M.; Lee, J. H. 2007. Development of a simplified design procedure for determining layer thickness in long-life pavement, Transportation Research Record 2037: 76-85. http://dx.doi.org/10.3141/2037-07

[14] Gui, J. (G); Phelan, P. E.; Kaloush, K. E.; Golden, J. S. 2007. Impact of pavement thermophysical properties on surface temperatures, Journal of Materials in Civil Engineering 19(8): 683-690. http://dx.doi.org/10.3141/1974-04

[15] Haas, R.; Tighe, S. L.; Falls, L. C. 2006. Determing return on long-life pavement investments, Transportation Research Record $1974: 10-17$.

[16] Koganzon, M. S.; Lugov, S. V. 2004. Raschiot i konstruirovaniie dorozhnykh odezhd po kriteriiu dopustimoi ostatochnoi deformacini, Nauka $i$ tekhnika v dorozhnoi otrasli 30(3): 17-19.

[17] Choi, J.-H.; Bahia, H. U. 2004. Life-cycle cost analysis - embedded Monte Carlo approach for modeling pay adjustament at state departmens of transportation, Transportation Research Record 1900: 86-93. http://dx.doi.org/10.3141/1900-10

[18] Pellinen, T. K.; Christensen, D. W.; Rove, G. M.; Sharok, M. 2004. Fatique transfer functions - how do they compare? Transportation Research Record 1896: 77-87. http://dx.doi.org/10.3141/1896-08

[19] Chatti, K.; El Mohtar, C. S. 2004. Effect on different axle configuration on fatique life of asphalt concrete mixture, Transportation Research Record 1891: 121-130. http://dx.doi.org/10.3141/1891-15

[20] Kim, Y.-R.; Little, D. N.; Lytton, R. L. 2003. Fatique and healing characterization of asphalt mixtures, Journal of Materials in Civil Engineering 15(1): 75-83.

[21] ODN 218.046-01.2001. Proiektirovaniie nezhostkikh dorozhnykh odezhd. Otraslevyie dorozhnyie normy. Moskva. 144 s.

[22] Zhang, Z. M.; Leidy, J. P.; Kawa, I., et al. 2000. Impact of changing traffic characteristics and environmental condition on flexible pavement, Transportation Research Record 1730: 125-131. http://dx.doi.org/10.3141/1730-15

[23] Noureldin, A. S. 1997. Quantifying the effect of pavement performance characteristics, Transportation Research Record 1575: 75-84. http://dx.doi.org/10.3141/1575-11

[24] Ekdahl, P. 1999. Sensitivity Analysis of Two Deterioration Models for Flexible Pavements. Lund: Lund University. 102 p.

[25] Petkevičius, K. 2008. Automobilių keliu asfaltbetonio dangos būklès tyrimai ir ju rezultatu taikymas: habilitacijos procedūrai teikiamų mokslo darbų apžvalga [Investigation of motor roads asphalt concrete pavement condition and aplication of their results]. Vilnius: Technika. $40 \mathrm{p}$. 